\title{
DINAMIKA PERAN PENILAIAN DIRI DALAM MENINGKATKAN EMPLOYABILITY SISWA SMK
}

\author{
Muhamad Hasan Abdillah*1, Fatwa Tentama ${ }^{2}$, Herlina Siwi Widiana ${ }^{3}$ \\ Mahasiswa $^{1}$ dan Dosen ${ }^{2,3}$, Program Studi Magister Psikologi, Fakultas Pascasarjana \\ Universitas Ahmad Dahlan Yogyakarta \\ e-mail: *11addakhil.abdulloh@gmail.com, ${ }^{2}$ fatwa.tentama@psy.uad.ac.id, \\ ${ }^{3}$ herlina.widiana@psy.uad.ac.id
}

\begin{abstract}
Abstrak
Employability merupakan bagian penting yang harus dimiliki setiap individu dalam memasuki dunia kerja, karena employability mempengaruhi perilaku atau usaha individu dalam mencari pekerjaan, kualitas pekerjaan yang dipilih, dan hasil pencarian kerja. Penelitian ini bertujuan menyelidiki apakah penilaian diri mampu memprediksi tingkat employability siswa. Peneliti memilih siswa kelas XII SMK Muhammadiyah 1 Bambanglipuro sebagai subjek penelitian $(N=433)$ dengan kriteria telah melaksanakan praktek kerja industry. Sampel penelitian berjumlah 168 siswa yang terdiri dari siswa kelas TSM D, TKR, C, TKR D, MM A, RPL, dan TPHP. Pemilihan sampel dilakukan secara random dengan teknik cluster sampling. Skala model likert sebagai instrumen utama dalam mempreroleh data emprik. Untuk menjawab hipotesis peneliti menggunakan teknik regresi linier sederhana dengan bantuan program SPSS V.23. Berdasarkan hasil analisis diketahui bahwa penilaian diri memiliki pengaruh yang sangat signifikan terhadap tinggi rendahnya employability $(p<0,000)$. Temuan ini memberi bukti bahwa penilaian diri sebagai faktor internal cukup mampu dalam meningkatkan employability. Dengan demikian dapat disimpulkan bahwa faktor internal adalah salah satu faktor penting dalam memprediksi employability siswa SMK.
\end{abstract}

Kata kunci: Adaptasi Karir, Dunia Kerja, Employability, Penilain Diri, Perencanaan Karir

\section{PENDAHULUAN}

Employability memainkan peran penting dalam kemajuan karier dan pengembangan profesionalitas individu. Keampuan ini membantu individu memahami hal-hal yang dibutuhkan untuk mendapatkan, menjaga, dan melakukan pekerjaan dengan baik. ${ }^{1}$ Oleh karenanya rendahnya employability menjadi penghalang bagi individu

${ }^{1}$ Laura Brewer, Enhancing Youth Employability: What? Why? And How? Guide to Core Workskills (Geneva: International Labour Organization, 2013).

Al Qalam: Jurnal Ilmiah Keagamaan dan Kemasyarakatan

Vol. 15, No. 1, Januari-Juni 2021 
Muhamad Hasan Abdillah, Fatwa Tentama, Herlina Siwi Widiana: Dinamika Peran Penilaian Diri dalam Meningkatkan Employability Siswa SMK

memasuki dunia kerja. ${ }^{2}$ Mengacu pada temuan tersebut, hal ini telah menarik minat beberapa kalangan peneliti industri untuk mengkaji lebih dalam fakta-fakta tentang employability (seperti Alvarez-Gonzalez, López-Miguens, \& Caballero; ${ }^{3}$ OkaySomerville \& Scholarios; ${ }^{4}$ Qenani, MacDougal, \& Sexton ${ }^{5}$ ), namun di Indonesia sendiri penelitian tentang employability masih terbatas, karena employability belum dipahami sebagai faktor penting dalam perencanaan karir yang perlu ditanamkan sejak bangku sekolah, ${ }^{6}$ khususnya sekolah kejuruan yang tujuan utamanya adalah mencetak sumber daya manusia mudah terserap dunia kerja. Dalam literatur ini kami ingin memperluas pemahaman tentang employability dalam setting budaya Indonesia, kami mengusulkan faktor internal berupa penilaian diri sebagai prediktor dari tinggi rendahnya employability. Hipotesis yang kami usulkan adalah "ada pengaruh penilaian diri terhadap employability".

Mengembangkan dan meningkatkan employability pada dasarnya adalah hal yang sangat penting dilakukan lembaga pendidikan, ${ }^{7}$ seperti halnya di beberapa Negara maju di mana employability telah menjadi perhatian utama. ${ }^{8}$ Employability sebagai bekal yang memudahkan individu mendapatkan pekerjaan di masa depan. Kemampuan ini membantu individu mengelola karier dengan lebih maksimal. ${ }^{9}$ Selain itu juga akan meningkatkan keterampilan-keterampilan dasar dalam berbisnis, seperti kemampuan kerja tim, komunikasi, manajemen diri, analisis dan pemikiran kritis. ${ }^{10}$ Employability didefinisikan sebagai bentuk keterampilan khusus yang memungkinkan individu untuk mengidentifikasi dan menyadari peluang karir. ${ }^{11}$ Individu dengan employability akan mempersiapkan diri semaksimal mungkin dalam upaya menghadapi persaingan pasar dunia kerja. ${ }^{12}$ Individu mengetahui spesialisasi yang dimilikinya untuk menerapkan pengetahuan dan keterampilannya dalam berbagai situasi dan perubahan pasar serta

${ }^{2}$ Yao-Fen Wang and Chen-Tsang Tsai, "Employability of Hospitality Graduates: Student and Industry Perspectives," Journal of Hospitality \& Tourism Education 26, no. 3, (2014): 125-135.

3 Paula Álvarez-González, María Jesús López-Miguens, and Gloria Caballero, "Perceived Employability in University Students: Developing an Integrated Model," Career Development International 22, no. 3, (2017): 280-299.

${ }^{4}$ Monika Stachowiak-Kudła and Janusz Kudła, "Position, Possession or Process? Understanding Objective and Subjective Employability During University-to-Work Transitions," Studies in Higher Education 42, no. 7, (2017): 1275-1291.

${ }^{5}$ Eivis Qenani and Carol Sexton, “An Empirical Study of Self-Perceived Employability: Improving The Prospects for Student Employment Success in an Uncertain Environment," Active Learning in Higher Education 1, no. 53, (2014): 199-213.

6 Per Ronnås and Leyla Shamchiyeva, Employment Diagnostic Analysis: Maluku, Indonesia (Geneva: International Labour Organization, 2011).

7 Stephanie Jameson, "A Case Study of International Hospitality Students Development of Employability Skills," Tourism and Hospitality Research, (2008): 57-59.

${ }^{8}$ Huimin Gu, Raphael Kavanaugh, and Yu Cong, "Empirical Studies of Tourism Education in China," Journal of Teaching in Travel \& Tourism 7, no. 1, (2007): 3-24.

${ }^{9}$ Narelle Hess, Denise Jepsen, and Nicky Dries, "Career and Employer Change in The Age of The 'Boundaryless' Career,' Journal of Vocational Behavior 81, no. 2, (2012): 280-288.

10 Kevin Lowden, Stuart Hall, Dely Elliot, and Jon Lewin, Employers' Perceptions of The Employability Skills of New Graduates (London: Edge Foundation, 2011).

11 Mel Fugate and Blake Ashforth, "Employability: The Construct, Its Dimensions, and Applications," Academy of Management Proceedings, no. 1, (2003): 1-6.

${ }^{12}$ Ans De Vos, Sara De Hauw, and Beatrice Van der Heijden, "Competency Development and Career Success: The Mediating Role of Employability,” Journal of Vocational Behavior 79, no. 2, (2011): 438-447.

Al Qalam: Jurnal Ilmiah Keagamaan dan Kemasyarakatan Vol. 15, No. 1, Januari-Juni 2021 
Muhamad Hasan Abdillah, Fatwa Tentama, Herlina Siwi Widiana: Dinamika Peran Penilaian Diri dalam Meningkatkan Employability Siswa SMK

memiliki keinginan untuk terus mengembangkan pengetahuan dan keterampilan khususnya. ${ }^{13}$ Individu mampu mengambil tindakan dengan tepat dan efektif, memiliki tujuan yang jelas untuk dicapai, serta memiliki kemauan untuk terus belajar dari pengalamannya, baik sebagai individu maupun dalam hubungan dengan orang lain. ${ }^{14}$

Pada dasarnya employability mencerminkan bagaimana individu mempersepsikan peluang pekerjaan, seperti menentukan perilaku pencarian pekerjaan, pilihan pekerjaan, dan hasil pencarian kerja. Selain itu, employability juga berkaitan dengan kualitas suatu pekerjaan. ${ }^{15}$ Individu mungkin dapat memperoleh pekerjaan, tetapi mungkin di bawah tingkat keterampilan yang dimilikinya atau dalam pekerjaan bergaji rendah, tidak diinginkan, dan tidak berkelanjutan. ${ }^{16}$ Individu yang memperoleh pekerjaan namun dengan klasifikasi tersebut belum mencerminkan memiliki employability. ${ }^{17}$ Individu dengan employability adalah individu yang menggunakan pengetahuan, keterampilan, dan pemahamannya untuk mencari dan mendapatkan pekerjaan. ${ }^{18}$ Individu menggunaan kompetensinya secara optimal untuk bergerak secara mandiri (wirausaha) di pasar tenaga kerja dan mengembangkan potensinya melalui pekerjaan yang berkelanjutan. ${ }^{19}$ Individu akan mencari informasi lingkungan kerja dan mengidentifikasi beragam alternatif peluang karir, sehingga individu menyadari karir apa saja yang dapat dikejar atau diperoleh sesuai dengan bidang keahliannya. ${ }^{20}$ Proses ini dapat meminimalisir ketidakpastian pekerjaan atau kegagalan bisnis. ${ }^{21}$

\section{Literatur Riview: Penilaian Diri terhadap Employability}

Sejauh mana pendidikan kejuruan dapat memberikan dasar yang kuat untuk pengembangan employability tergantung pada sejumlah faktor. ${ }^{22}$ Salah satu faktor di

${ }^{13}$ Fatwa Tentama and Muhamad Hasan Abdillah, "Student Employability Examined from Academic Achievement and Self-Concept," International Journal of Evaluation and Research in Education 8, no. 2, (2019): 243-248.

${ }^{14}$ Mantz Yorke, Employability in Higher Education: What It Is - What It Is Not (York: The Higher Education Academy, 2006).

${ }^{15}$ Steven Mcintosh, "Further Analysis of The Returns to Academic and Vocational Qualifications," Oxford Bulletin of Economics and Statistics 68, no. 2, (2006): 225-251.

${ }^{16}$ Erik Berntson and Staffan Marklund, "The Relationship Between Perceived Employability and Subsequent Health," Work \& Stress 21, no. 3, (2007): 279-292.

17 Jim Hillage and Emma Pollard, Employability: Developing a Framework for Policy Analysis (London: Department for Education and Employment, 1998).

18 Fatwa Tentama, Subardjo, and Muhamad Hasan Abdillah, "Motivation to Learn and Social Support Determine Employability among Vocational High School Students," International Journal of Evaluation and Research in Education 8, no. 2, (2019): 237-242.

${ }^{19}$ Dieter Dohmen, Economics of Vocational Education and Training: Introduction and Overview (Berlin: Institute for Education and Socio-Economic Research and Consulting, 2007).

${ }^{20}$ Dominik Froehlich, Simon Beausaert, and Mien Segers, "Age, Employability and The Role of Learning Activities and Their Motivational Antecedents: A Conceptual Model," The International Journal of Human Resource Management 26, no. 16, (2015): 2087-2101.

21 Johannes Thijssen, Beatrice Van der Heijden, and Beatrice Van der Heijden, "Toward The Employability Link Model: Current Employment Transition to Future Employment Perspectives," Human Resource Development Review 7, no. 2, (2008): 165-183.

${ }^{22}$ Sandra Bohlinger, Ulrika Haake, Christian Helms Jørgensen, Hanna Toiviainen, and Andreas Wallo, Working and Learning in Times of Uncertainty: Challenges to Adult, Professional and Vocational Education (Rotterdam: Sense Publishers, 2015).

Al Qalam: Jurnal Ilmiah Keagamaan dan Kemasyarakatan Vol. 15, No. 1, Januari-Juni 2021 
Muhamad Hasan Abdillah, Fatwa Tentama, Herlina Siwi Widiana: Dinamika Peran Penilaian Diri dalam Meningkatkan Employability Siswa SMK

antaranya adalah penilaian diri. ${ }^{23}$ Penilaian diri merupakan keterampilan penting yang dibutuhkan individu untuk pengembangan karir profesionalitasnya di masa depan. ${ }^{24}$ Penilaian diri didefinisikan sebagai proses di mana individu menilai kinerjanya terhadap kriteria standar yang telah ditentukan dalam penetapan tujuan yang lebih mandiri dan untuk merefleksikan diri. ${ }^{25}$ Proses penilaian diri dilakukan dengan dua jenis kegiatan utama, yaitu: pencarian umpan balik dan refleksi diri. Umpan balik merupakan informasi spesifik yang didapatkan individu untuk memfasilitasi hasil belajarnya dan biasanya digunakan untuk menginformasikan tentang kelebihan, kelemahan, dan kemajuan pembelajarannya. ${ }^{26}$ Refleksi diri mengacu pada proses dimana individu bertanggung jawab untuk mencari informasi spesifik dengan tujuan menggambarkan dan mengevaluasi hasil pembelajarannya. ${ }^{27}$ Individu perlu mengumpulkan umpan balik tentang kualitas dirinya dari berbagai sumber yang memungkinkan dirinya untuk merefleksikan alasan di balik kinerjanya. ${ }^{28}$ Penilaian diri yang positif dapat membantu mengembangkan rasa tanggung jawab internal untuk pembelajaran diri. Rasa tanggung jawab ini akan memberi keyakinan dan motivasi untuk mengendalikan dan mengarahkan upaya yang diperlukan untuk pencapaian yang lebih tinggi. ${ }^{29}$

\section{METODE PENELITIAN}

\section{Partisipan dan Prosedur}

Populasi dalam penelitian ini adalah seluruh siswa kelas XII SMK Muhammadiyah 1 Bambanglipuro yang berjumlah 433 siswa dengan kriteria mengikuti program Praktik Kerja Industri (PRAKERIN). Asumsinya adalah siswa dengan pengalaman Prakterk Kerja Indutri memiliki pemahaman dan keterampilan sesuai bidang peminatannya yang memungkinkanya memiliki employability yang lebih baik. Sedangkan sampel dalam penelitian ini berjumlah 168 siswa yang ditentukan berdasarkan tingkat kesalahan 10\% mengacu pada tabel Isaac dan Michael (1995). Pemilihan sampel dilakukan dengan random cluster sampling. Langkah-langkahnya adalah: 1) peneliti menentukan jumlah cluster dari seluruh populasi; 2) Peneliti memilih cluster yang akan

${ }^{23}$ Ike Onyishi, Ibeawuchi Enwereuzor, Afam Ituma, and Tochukwu Omenma, "The Mediating Role of Perceived Employability in The Relationship Between Core Self-Evaluations and Job Search Behaviour," Career Development International 20, no. 6, (2015): 604-626.

${ }^{24}$ Michael Wride, Assessment: Guide to Self-Assessment (Dublin: University of Dublin, 2017).

${ }^{25}$ Roseanna Bourke and Mandia Mentis, "Self-assessment as a Process For Inclusion," International Journal of Inclusive Education 17, no. 8, (2013): 854-867.

${ }^{26}$ John Hattie and Helen Timperley, "The power of feedback," Review of Educational Research 77, no. 1 , (2007): 81-112.

${ }^{27}$ Nicola Kirby and Colleen Downs, "Self-Assessment and The Disadvantaged Student: Potential for Encouraging Self-Regulated Learning?," Assessment \& Evaluation in Higher Education 32, no. 4, (2007): 475-494.

${ }^{28}$ Guihyun Park, Aaron Schmidt, and Richard DeShon, “A Process Model of Goal Orientation and Feedback Seeking," Human Performance 20, no. 2, (2007): 119-145.

${ }^{29}$ Hartuti, Fatwa Tentama, Muhamad Hasan Abdillah, and Rifa Nur Alifah, "Physical Self, Social Self, Psychological Self, and Moral Self in Reflecting Self-Concept," International Journal of Sciences: Basic and Applied Research 54, no. 1, (2020): 158-169.

Al Qalam: Jurnal Ilmiah Keagamaan dan Kemasyarakatan Vol. 15, No. 1, Januari-Juni 2021 
Muhamad Hasan Abdillah, Fatwa Tentama, Herlina Siwi Widiana: Dinamika Peran Penilaian Diri dalam Meningkatkan Employability Siswa SMK

dijadikan sampel uji coba dan sampel penelitian dengan cara menggambar (untuk menentukan jumlah cluster yang dipilih dapat menggunakan tabel Isaac dan Michael dengan tingkat kesalahan $1 \%, 5 \%$, atau $10 \%$ Ada lima klaster dalam penelitian ini yaitu: kelas Teknik Sepeda Motor (TSM), kelas Teknik Kendaraan Ringan (TKR), kelas Multimedia (MM), kelas Rekayasa Perangkat Lunak (RPL), dan kelas Teknik Pengolahan Hasil Pertanian (TPHP). A, B, C, D, E), TKR (A, B, C, D, E, F), MM (A, B), RPL, dan TPHP dipilih dalam dua kelas sebagai sampel uji coba (TSM B dan TSM E) dan enam kelas sebagai sampel penelitian (TSM D, TKR, C, TKR D, MM A, RPL, dan TPHP).

\section{Intrumen Penelitian}

Penelitian ini menggunakan skala model likert sebagai instrumen utama dalam memperoleh data empirik dari employability dan penilaian diri. Skala employability merupakan hasil modifikasi dari penelitian sebelumnya sementara penilaian diri, dan efikasi diri disusun sendiri oleh peneliti. Skala tersebut kemudian diujicobakan pada 59 siswa untuk memperoleh validitas dan reliabilitas pengukuran. Adapun penjelasan masing-masing skala sebagai berikut:

\section{Skala Employability}

Peneliti memodifikasi skala employability dari Tentama dan Anindita, ${ }^{30}$ yang penyusunannya mengacu pada dimensi employability dari Fugate, Kinicki, dan Ashforth, yaitu: career identity, personal adaptability, dan social and human capital. Dimensi career identity dicerminkan oleh item "Saya memiliki keterampilan yang dibutuhkan di dunia kerja" dan "Saya secara aktif terlibat dalam praktik di sekolah". Dimensi personal adaptability tercermin dalam item "Saya mampu menyelesaikan setiap masalah dalam kerja praktek dengan kemampuan saya" dan "Saya mampu berpikir positif bahkan dalam situasi sulit". Dimensi social and human capital tercermin pada item "Saya merasa pengalaman praktik di sekolah dapat membantu mendapatkan pekerjaan" dan "Saya memiliki teman yang dapat membantu mendapatkan referensi pekerjaan". Berdasarkan hasil pengujian diperoleh 13 item valid yang siap digunakan untuk penelitian dengan koefisien alpha Cronbach sebesar 0,83 dan indeks beda bergerak dari 0,32 menjadi $0,77^{31}$

\section{Skala Penilaian Diri}

Dasar dari penyusunan skala penilaian diri peneliti susun sendiri dengan mengacu pada dimensi penilaian diri menurut Gecas (dalam Mruk), yang terdiri dari: self-power dan self-worth. Dimensi self-power tercermin dalam item "Saya berkontribusi pada tugas kelompok" dan "Saya membantu teman belajar memahami materi pelajaran". Dimensi

\footnotetext{
${ }^{30}$ Fatwa Tentama and Wiwid Anindita, "Employability Scale: Construct Validity and Reliability," International Journal of Scientific \& Technology Research 9, no. 4, (2020): 3166- 3170.

${ }^{31}$ Mel Fugate, Angelo Kinicki, and Blake Ashforth, "Employability: A Psycho-Social Construct, Its Dimensions, and Applications,” Journal of Vocational Behavior 65, no. 1, (2004): 14-38.
}

Al Qalam: Jurnal Ilmiah Keagamaan dan Kemasyarakatan Vol. 15, No. 1, Januari-Juni 2021 
Muhamad Hasan Abdillah, Fatwa Tentama, Herlina Siwi Widiana: Dinamika Peran Penilaian Diri dalam Meningkatkan Employability Siswa SMK

self-worth tercermin dalam item "Saya menghormati pendapat orang lain" dan "Saya mematuhi peraturan sekolah". Berdasarkan hasil pengujian diperoleh 10 item valid yang siap digunakan untuk penelitian dengan koefisien alpha Cronbach sebesar 0,80 dan indeks beda bergerak dari 0,32 menjadi $0,69 .^{32}$

\section{Analisis Data}

Analisis data yang digunakan dalam penelitian ini adalah analisis regresi linier sederhana dengan program SPSS 23. Analisis regresi linier sederhana digunakan untuk menguji asumsi penelitian (meliputi uji normalitas dan uji linieritas) dan menguji hipotesis penelitian.

\section{HASIL DAN PEMBAHASAN}

\section{Uji Asumsi}

Uji asumsi merupakan syarat yang harus terpenuhi dalam melakukan analisis statistik parametrik. Dalam analisis parametrik regresi sederhana beberapa asumsi yang harus terpenuhi mencakup uji normalitas dan uji linieritas. Berikut hasil analisis dari masing-masing asumsi:

\section{Uji Normalitas}

Uji normalitas bertujuan mengetahui apakah sampel yang digunakan penelitian terdistribusi dengan normal (representatif). Peneliti menggunakan teknik KolmogorovSmirnov Test $(K S-Z)$ dalam pengujian normalitas dengan kriteria data dikatakan normal apabila $\mathrm{p}>0,05$. Dari hasil uji normalitas residual diperoleh skor Kolmogorov-Smirnov $Z$ sebesar 1,15 dengan taraf signifikasi 0,144 ( $\mathrm{p}>0,05)$ yang artinya sampel penelitian mampu mewakili populasi. Hasil uji normalitas dapat dilihat pada Tabel 1.

Tabel 1 Analisis Uji Normalitas Residual

\begin{tabular}{|l|c|c|c|}
\hline & Kolmogorov-Smirnov $\boldsymbol{Z}$ & Sig. & Keterangan \\
\hline Unstandardized Residual & 1,15 & 0,144 & Normal \\
\hline
\end{tabular}

\section{Uji Linieritas}

Uji linieritas bertujuan untuk melihat apakah ada garis linier yang menghubungkan antara nilai-nilai variabel independen dengan nilai-nilai variabel dependen. Peneliti menggunakan kaidah $F$ Linearity dalam pengujian linieritas. Dalam kaidah ini data dikatakan linier apabilan $\mathrm{p}<0,05$. Dari hasil uji linieritas antara penilaian diri dengan employability, diperoleh nilai $F$ Linearity sebesar 9,75 dengan taraf signifikansi $0,000(\mathrm{p}<0,05)$. Artinya variabel penilaian diri terhubung secara linier dengan variabel employability. Hasil uji linieritas dapat dilihat pada Tabel 2.

${ }^{32}$ Christopher Mruk, Self-Esteem and Positive Psychology: Research, Theory, and Practice (New York: Springer Publishing Company, 2013).

Al Qalam: Jurnal Ilmiah Keagamaan dan Kemasyarakatan

Vol. 15, No. 1, Januari-Juni 2021 
Muhamad Hasan Abdillah, Fatwa Tentama, Herlina Siwi Widiana: Dinamika Peran Penilaian Diri dalam Meningkatkan Employability Siswa SMK

Tabel 2 Analisis Uji Linearitas

\begin{tabular}{|c|c|c|c|}
\hline Variabel & F Linearity & Sig. & Keterangan \\
\hline Penilaian Diri dengan Employability & 9,75 & 0,000 & Linear \\
\hline
\end{tabular}

\section{Uji Hipotesis: Analisis Regresi Linier Sederhana}

Berdasarkan hasil analisis regresi linier sederhana diperoleh nilai $\mathrm{F}$ pada penilaian diri terhadap employability sebesar 94,87 dengan taraf signifikansi $0,000(\mathrm{p}<0,01)$. Artinya ada pengaruh yang sangat signifikan penilaian diri terhadap employability dengan sumbangan efektif ( $R$ Square) yang dihasilkan sebesar 36,4\%. Hasil analisis regresi berganda dapat dilihat pada Tabel 3 .

Tabel 3 Analisis Regresi Linear Berganda

\begin{tabular}{|c|c|c|c|c|}
\hline Variabel & F & R Square & Sig. & Keterangan \\
\hline Penilaian diri Diri terhadap Employability & 94,87 & 0,364 & 0,000 & Sangat Signifikan \\
\hline
\end{tabular}

Berdasarkan hasil analisis regresi linier sederhana diketahui bahwa hipotesis yang diajukan peneliti terbukti, yaitu: ada pengaruh yang sangat signifikan penilaian diri terhadap employability. Penilain diri berfungsi sebagai proses evaluasi diri yang positif atas rangkaian kekuatan, potensi diri, dan kesiapan kerja inidividu. Kemampuan ini memungkinkan individu menilai dirinya sendiri mampu mengatasi berbagai kendala selama pencarian kerja dengan strategi pemecahan masalah yang lebih baik. Individu menilai dirinya mampu beradaptasi dengan berbagai tuntutan dunia kerja, pantang menyerah dalam menghadapi kesulitan mencari pekerjaan, dan yakin bahwa usahanya akan membuahkan hasil (mendapatkan pekerjaan) di masa depan.

Temuan ini sejalan dengan beberapa hasil studi di luar Indonesia, seperti temuan Onyishi, Enwereuzor, Ituma, dan Omenma yang melaporkan bahwa individu dengan penilaian diri yang baik menunjukkan tingkat employability dan intensitas perilaku pencarian kerja yang tinggi setelah lulus. ${ }^{33}$ Individu menganggap dirinya memiliki keterampilan yang dibutuhkan pasar tenaga kerja, sehingga memudahkan dirinya untuk dipekerjakan dan mencari pekerjaan. ${ }^{34}$ Menurut Kammeyer-Mueller, Judge, dan Scott individu yang mengetahui kekuatan dan potensi diri cenderung lebih mudah menerapkan ilmunya untuk merencanakan karir, strategi pencarian kerja, dan beradaptasi dengan tuntutan dunia kerja. ${ }^{35}$ Kemampuan ini merupakan keunggulan unik dalam mencari dan

${ }^{33}$ Ike Onyishi, Ibeawuchi Enwereuzor, Afam Ituma, and Tochukwu Omenma, "The Mediating Role of Perceived Employability in The Relationship Between Core Self-Evaluations and Job Search Behaviour," Career Development International 20, no. 6, (2015): 604-626.

34 Timothy Judge, "Core Self-Evaluations and Work Success," Current Directions in Psychological Science 18 , no. 1, (2009): 58-62.

35 John Kammeyer-Mueller, Timothy Judge, and Brent Scott, "The Role of Core Self-Evaluations in The Coping Process,” Journal of Applied Psychology 94, no. 1, (2009): 177-195.

Al Qalam: Jurnal Ilmiah Keagamaan dan Kemasyarakatan Vol. 15, No. 1, Januari-Juni 2021 
Muhamad Hasan Abdillah, Fatwa Tentama, Herlina Siwi Widiana: Dinamika Peran Penilaian Diri dalam Meningkatkan Employability Siswa SMK

mendapatkan pekerjaan. ${ }^{36}$ Dengan demikian dapat dikatakan bahwa evaluasi diri merupakan faktor esensial dari employability, dimana tingkat penilaian diri memprediksi tingkat employability.

Dalam pendidikan kejuruan penerapan penilaian diri merupakan bagian penting dari upaya untuk meningkatkan employability. ${ }^{37}$ Dengan menanamkan sikap pemantauan, penilaian, dan mengevaluasi hasil pencapaian untuk mencapai tujuan pembelajaran yang lebih baik akan membantu individu dalam mengenali peningkatan berkelanjutan dan mengidentifikasi pendekatan belajar untuk mencapai hasil yang terbaik. Individu cenderung memiliki keterampilan yang tepat dan dapat secara efektif menerapkan dan mengembangkan pembelajaran di tempat kerja ketika mampu secara mandiri melakukan penilaian diri. ${ }^{38}$ Dengan demikian dapat dipahami bahwa penilaian diri merupakan salah satu cara untuk meningkatkan keterampilan dan kesiapan kerja individu. Proses ini dapat membantu individu meningkatkan keterampilan pemecahan masalah dan kemampuan berpikir kritis. ${ }^{39}$

Dengan menilai tahap pengembangan kompetensi diri, individu akan memantau perkembangan employabilitynya secara berkala. Individu menjadi pribadi yang lebih bertanggung jawab ketika secara aktif bersedia melakukan penilaian terhadap hasil dari pekerjaan atau pencapaiannya. ${ }^{40}$ Dengan demikian dapat dikatakan peran penilaian diri dalam pembelajaran keterampilan kerja sangatlah jelas, dimana proses ini dipandang sebagai metode yang berharga untuk meningkatkan kesadaran individu tentang pemahaman dan pencapaiannya. Sebagaimana fungsi penilaian diri diantaranya adalah untuk mengembangkan kecenderungan belajar dan peningkatan keterlibatan dalam proses pembelajaran. ${ }^{41}$ Persepsi diri yang meningkat dan pola penilaian yang konsisten akan mengarah pada peningkatan employability. ${ }^{42}$

Dari segi kebaruan, peneliti belum menemukan penelitian yang serupa dengan penelitian ini yang ada di Indonesia, baik dari variabel independen yang diajukan, subjek penelitian, hingga lokasi penelitian. Dengan demikian penelitian ini merupakan satu-

36 Timothy Judge and John Kammeyer-Mueller, "Implications of Core Self-Evaluations for a Changing Organizational Context,” Human Resource Management Review 21, no. 4, (2011): 331-341.

${ }^{37}$ Fatwa Tentama and Muhamad Hasan Abdillah, "Student Employability Examined from Academic Achievement and Self-Concept," International Journal of Evaluation and Research in Education 8, no. 2, (2019): 243-248.

38 Timothy Judge and John Kammeyer-Mueller, "Implications of Core Self-Evaluations for a Changing Organizational Context," Human Resource Management Review 21, no. 4, (2011): 331-341.

39 Timothy Judge, "Core Self-Evaluations and Work Success," Current Directions in Psychological Science 18, no. 1, (2009): 58-62.

${ }^{40}$ Ike Onyishi, Ibeawuchi Enwereuzor, Afam Ituma, and Tochukwu Omenma, "The Mediating Role of Perceived Employability in The Relationship Between Core Self-Evaluations and Job Search Behaviour," Career Development International 20, no. 6, (2015): 604-626.

${ }^{41}$ Kath MacDonald, "A Reflection on The Introduction of A Peer and Self Assessment Initiative," Practice and Evidence of the Scholarship of Teaching and Learning in Higher Education 6, no. 1, (2011): 27-42.

42 Traci Sitzmann, Katherine Ely, Kenneth Brown, and Kristina Bauer, "Self-Assessment of Knowledge: A Cognitive Learning or Affective Measure?," Academy of Management Learning \& Education 9, no. 2, (2010): 169-191.

Al Qalam: Jurnal Ilmiah Keagamaan dan Kemasyarakatan Vol. 15, No. 1, Januari-Juni 2021 
Muhamad Hasan Abdillah, Fatwa Tentama, Herlina Siwi Widiana: Dinamika Peran Penilaian Diri dalam Meningkatkan Employability Siswa SMK

satunya literatur yang membahas tentang pengaruh penilaian diri terhadap employability pada siswa SMK di Indonesia.

\section{KESIMPULAN}

Berdasarkan hasil analisis dan diskusi menunjukkan bahwa seberapa penting faktor penilaian diri terlibat dalam proses pembentukan employability siswa. Dengan demikian dapat disumpulkan bahwa siswa akan lebih siap memasuki dunia kerja ketika memiliki kemampuan penilaian diri yang baik.

\section{DAFTAR PUSTAKA}

Álvarez-González, Paula., María Jesús López-Miguens., and Gloria Caballero. "Perceived Employability in University Students: Developing an Integrated Model." Career Development International 22, no. 3, (2017): 280-299. https://doi.org/10.1108/CDI08-2016-0135.

Berntson, Erik., and Staffan Marklund. "The Relationship Between Perceived Employability and Subsequent Health.” Work \& Stress 21, no. 3, (2007): 279-292. https://doi.org/10.1080/02678370701659215.

Bohlinger, Sandra., Ulrika Haake., Christian Helms Jørgensen., Hanna Toiviainen., and Andreas Wallo. Working and Learning in Times of Uncertainty: Challenges to Adult, Professional and Vocational Education. Rotterdam: Sense Publishers, 2015.

Bourke, Roseanna., and Mandia Mentis. "Self-assessment as a Process For Inclusion." International Journal of Inclusive Education 17, no. 8, (2013): 854-867. https://doi.org/10.1080/13603116.2011.602288.

Brewer, Laura. Enhancing Youth Employability: What? Why? And How? Guide to Core Workskills. Geneva: International Labour Organization, 2013.

De Vos, Ans., Sara De Hauw., and Beatrice Van der Heijden. "Competency Development and Career Success: The Mediating Role of Employability." Journal of Vocational Behavior 79, no. 2, (2011): 438-447. https://doi.org/10.1016/j.jvb.2011.05.010.

Dohmen, Dieter. Economics of Vocational Education and Training: Introduction and Overview. Berlin: Institute for Education and Socio-Economic Research and Consulting, 2007.

Froehlich, Dominik., Simon Beausaert., and Mien Segers. “Age, Employability and The Role of Learning Activities and Their Motivational Antecedents: A Conceptual Model." The International Journal of Human Resource Management 26, no. 16, (2015): 2087-2101. https://doi.org/10.1080/09585192.2014.971846.

Fugate, Mel., and Blake Ashforth. "Employability: The Construct, Its Dimensions, and Applications." Academy of Management Proceedings, no. 1, (2003): 1-6. https://doi.org/10.5465/ambpp.2003.13792496.

Fugate, Mel., Angelo Kinicki., and Blake Ashforth. "Employability: A Psycho-Social Construct, Its Dimensions, and Applications." Journal of Vocational Behavior 65, 
Muhamad Hasan Abdillah, Fatwa Tentama, Herlina Siwi Widiana: Dinamika Peran Penilaian Diri dalam Meningkatkan Employability Siswa SMK

no. 1, (2004): 14-38. https://doi.org/10.1016/j.jvb.2003.10.005

$\mathrm{Gu}$, Huimin., Raphael Kavanaugh., and Yu Cong. "Empirical Studies of Tourism Education in China." Journal of Teaching in Travel \& Tourism 7, no. 1, (2007): 324. https://doi.org/10.1300/J172v07n01_02.

Hartuti., Fatwa Tentama., Muhamad Hasan Abdillah., and Rifa Nur Alifah. "Physical Self, Social Self, Psychological Self, and Moral Self in Reflecting Self-Concept.” International Journal of Sciences: Basic and Applied Research 54, no. 1, (2020): 158-169.

Hattie, John., and Helen Timperley. "The power of feedback." Review of Educational Research 77, no. 1, (2007): 81-112. https://doi.org/10.3102/003465430298487.

Hess, Narelle., Denise Jepsen., and Nicky Dries. "Career and Employer Change in The Age of The 'Boundaryless' Career." Journal of Vocational Behavior 81, no. 2, (2012): 280-288. https://doi.org/10.1016/j.jvb.2011.10.009.

Hillage, Jim., and Emma Pollard. Employability: Developing a Framework for Policy Analysis. London: Department for Education and Employment, 1998.

Jameson, Stephanie. "A Case Study of International Hospitality Students Development of Employability Skills." Tourism and Hospitality Research, (2008): 57-59.

Judge, Timothy. "Core Self-Evaluations and Work Success." Current Directions in Psychological Science 18, no. 1, (2009): 58-62. https://doi.org/10.1111/j.14678721.2009.01606.x.

Judge, Timothy., and John Kammeyer-Mueller. "Implications of Core Self-Evaluations for a Changing Organizational Context." Human Resource Management Review 21, no. 4, (2011): 331-341. https://doi.org/10.1016/j.hrmr.2010.10.003.

Kammeyer-Mueller, John., Timothy Judge., and Brent Scott. "The Role of Core SelfEvaluations in The Coping Process." Journal of Applied Psychology 94, no. 1, (2009): 177-195. https://doi.org/10.1037/a0013214.

Kirby, Nicola., and Colleen Downs. "Self-Assessment and The Disadvantaged Student: Potential for Encouraging Self-Regulated Learning?." Assessment \& Evaluation in Higher Education 32, no. 4, (2007): 475-494. https://doi.org/10.1080/02602930600896464.

Lowden, Kevin., Stuart Hall., Dely Elliot., and Jon Lewin. Employers' Perceptions of The Employability Skills of New Graduates. London: Edge Foundation, 2011.

MacDonald, Kath. "A Reflection on The Introduction of A Peer and Self Assessment Initiative." Practice and Evidence of the Scholarship of Teaching and Learning in Higher Education 6, no. 1, (2011): 27-42.

Mcintosh, Steven. "Further Analysis of The Returns to Academic and Vocational Qualifications." Oxford Bulletin of Economics and Statistics 68, no. 2, (2006): 225251. https://doi.org/10.1111/j.1468-0084.2006.00160.x.

Mruk, Christopher. Self-Esteem and Positive Psychology: Research, Theory, and Practice. New York: Springer Publishing Company, 2013.

Onyishi, Ike., Ibeawuchi Enwereuzor., Afam Ituma., and Tochukwu Omenma., "The Mediating Role of Perceived Employability in The Relationship Between Core SelfEvaluations and Job Search Behaviour." Career Development International 20, no. 6, (2015): 604-626. https://doi.org/10.1108/CDI-09-2014-0130. 
Muhamad Hasan Abdillah, Fatwa Tentama, Herlina Siwi Widiana: Dinamika Peran Penilaian Diri dalam Meningkatkan Employability Siswa SMK

Park, Guihyun., Aaron Schmidt., and Richard DeShon. "A Process Model of Goal Orientation and Feedback Seeking." Human Performance 20, no. 2, (2007): 119145. https://doi.org/10.1080/08959280701332042.

Qenani, Eivis., and Carol Sexton. "An Empirical Study of Self-Perceived Employability: Improving The Prospects for Student Employment Success in an Uncertain Environment." Active Learning in Higher Education 1, no. 53, (2014): 199-213. https://doi.org/10.1177/1469787414544875.

Ronnås Per., and Leyla Shamchiyeva. Employment Diagnostic Analysis: Maluku, Indonesia. Geneva: International Labour Organization, 2011.

Sitzmann, Traci., Katherine Ely., Kenneth Brown., and Kristina Bauer. "Self-Assessment of Knowledge: A Cognitive Learning or Affective Measure?." Academy of Management Learning \& Education 9, no. 2, (2010): 169-191. https://doi.org/10.5465/amle.9.2.zqr169.

Stachowiak-Kudła, Monika., and Janusz Kudła. "Position, Possession or Process? Understanding Objective and Subjective Employability During University-to-Work Transitions." Studies in Higher Education 42, no. 7, (2017): 1275-1291. https://doi.org/10.1080/03075079.2015.1091813.

Tentama, Fatwa., and Muhamad Hasan Abdillah. "Student Employability Examined from Academic Achievement and Self-Concept," International Journal of Evaluation and Research in Education 8, no. 2, (2019): 243-248. https://doi.org/10.11591/ijere.v8i2.18128.

Tentama, Fatwa., and Wiwid Anindita. "Employability Scale: Construct Validity and Reliability." International Journal of Scientific \& Technology Research 9, no. 4, (2020): 3166- 3170.

Tentama, Fatwa., Subardjo., and Muhamad Hasan Abdillah. "Motivation to Learn and Social Support Determine Employability among Vocational High School Students." International Journal of Evaluation and Research in Education 8, no. 2, (2019): 237242. http://doi.org/10.11591/ijere.v8i2.18188.

Thijssen, Johannes., Beatrice Van der Heijden., and Beatrice Van der Heijden. "Toward The Employability Link Model: Current Employment Transition to Future Employment Perspectives." Human Resource Development Review 7, no. 2, (2008): 165-183. https://doi.org/10.1177/1534484308314955.

Wang, Yao-Fen., and Chen-Tsang Tsai. "Employability of Hospitality Graduates: Student and Industry Perspectives." Journal of Hospitality \& Tourism Education 26, no. 3, (2014): 125-135. https://doi.org/10.1080/10963758.2014.935221.

Wride, Michael. Assessment: Guide to Self-Assessment. Dublin: University of Dublin, 2017.

Yorke, Mantz. Employability in Higher Education: What It Is - What It Is Not. York: The Higher Education Academy, 2006. 